\title{
Michał Rauszer
}

mrauszer@gmail.com

Zakład Interdyscyplinarnych Badań nad Kulturą

Uniwersytet Warszawski

\section{CHŁOP-NIEWOLNIK? PAŃSZCZYZNA W PERSPEKTYWIE ANTROPOLOGII HISTORII}

\author{
Peasant-Slave? Serfdom in the Perspective \\ of Anthropology of History
}

\begin{abstract}
Streszczenie: W artykule analizuję miejsce chłopów w strukturze społecznej gospodarki folwarczno-pańszczyźnianej na terenie Polski. Celem jest pokazanie struktury ekonomicznego wyzysku pracy chłopów w kontekście praktyk hegemonicznych szlachty. Choć gospodarka folwarczno-pańszczyźniana różniła się zdecydowanie od niewolnictwa w Nowym Świecie, to możemy w obu systemach znaleźć pewne podobieństwa. Sytuacja chłopów w ustroju folwarcznym opierała się na formalnym podporządkowaniu władzy szlachty, jednak ze względu na podobne pochodzenie etniczne obu grup szlachta, by utrzymać system, stworzyła ideologię odmiennego, sarmackiego pochodzenia ${ }^{1}$. Ideologia ta posłużyła jako narzędzie do wytworzenia między szlachtą i chłopami różnicy, która miała strukturę rasowej (zachowując oczywiście świadomość chronologii). Ta „rasowa” różnica służyła jako hegemoniczne uzasadnienie pracy niewolnej chłopów. W swoim artykule chciałbym pokazać zarówno społeczno-polityczne mechanizmy prowadzące do wyzysku, jak i to, na czym opierało się hegemoniczne uzasadnienie takich stosunków.
\end{abstract}

Słowa kluczowe: chłopi; niewolnictwo; praca niewolna; pańszczyzna.

Abstract: This papers involves analysis of the place of peasants in Polish Serfdom structure as well as in context of unfree labor. The goal is to show how structure of economical exploitation of peasants labor works in the context of hegemonic practices of landowners. System of Polish serfdom was in the very sense different from New World Slavery but we can find similarities. Situation of Polish peasants during serfdom was based on formal and social subsumtion under the rule of the landowners (there were also peasants owners). Due to this same ethnic background polish landowners create ideology of their Sarmatian origin. This ideology was a tool to build race differentiation between landowners and peasants. This racial differentiation serve as hegemonic justification of exploitation of the peasants. In my article I want to show both political and social mechanism lead to this exploitation as well as on what basis and on what resources this justification was endowed.

Keywords: peasants; slavery; unfree labor; serfdom.

\footnotetext{
${ }^{1}$ Widoczna różnica etniczna na tzw. kresach złączyła się z tą dystynkcją wytworzoną w stosunku do chłopów w ogóle.
} 
Celem mojego artykułu jest pokazanie politycznego i kulturowego kontekstu funkcjonowania figury „chłopa” w strukturze symbolicznej towarzyszącej gospodarce folwarczno-pańszczyźnianej (XVI-XIX wiek). Chcę podejść do kwestii chłopów od strony zarówno obiektywnych procesów ekonomicznych, i tutaj posłużę się porównaniem z niewolnictwem atlantyckim (tzw. New World Slavery) (Blackburn 2010: 4-5), jak i od strony praktyk hegemonicznych szlachty, która dążyła do wpisania chłopów w strukturę podległości. Będę starał się pokazać, że pomiędzy chłopami i czarnymi niewolnika$\mathrm{mi}$ istnieją diametralne różnice, jednak z perspektywy procesów ekonomicznych możemy wykazać, że zarówno jednych, jak i drugich łączy „praca niewolna”. Jest to termin określający pewną część pracy, którą grupa ludzi jest zmuszona wykonywać za darmo. Od samego pojęcia niewolnictwa odróżnia ją to, że nie koncentruje się np. na definiowaniu osoby w strukturze społecznej, ale na ekonomicznym wymiarze relacji własności. Przykładowo rzymskie i greckie definicje opisują niewolnika jako "mówiące narzędzie" (instrumentum vocale). Odnoszą się więc do własności (Anderson 2013: 22-25). Sam termin „niewolnictwo” może być używany w przypadku pracy niewolnej, jednak odróżnia się od niej tym, że, pozbawiony osadzenia w ekonomicznym wyzysku, przesuwa się do sfery retoryki. Pojęcie niewolnictwa może być używane do celów retorycznych, wskazania pola politycznego podziału i w takim dyskursie używali go np. amerykańscy liberałowie w stosunku do siebie, kiedy walczyli o uniezależnienie się od władzy monarszej.

Chciałbym tutaj pokazać, że niewolnictwo jako strategia retoryczna może być wykorzystywane także do hegemonicznego podporządkowania grupy ludzi (np. historycznych mieszkańców polskiej wsi przez szlachtę). W tym kontekście możemy wskazać na proces, w którym pojęcie niewolnictwa staje się pojęciem politycznym, służącym uzasadnieniu systemu pracy niewolnej. Jednak by tak się stało, muszą zajść następujące warunki: proces podporządkowania pracy grupy ludzi (wyzysk - praca niewolna), rasizm - postrzeganie grupy ludzi wykonującej pracę niewolną jako gorszych, odmiennych rasowo, biologicznie, etnicznie, bezmyślnych, predestynowanych do pracy niewolnej². Chcę zatem pokazać wzajemny splot procesu wprowadzania ekonomicznego wyzysku za pomocą pracy niewolnej i uzasadniania tego wyzysku przez kulturowe praktyki „rasizmu”.

\footnotetext{
${ }^{2}$ Rasizm jest pojęciem nowoczesnym, jednak ze względu na to, że najlepiej oddaje kulturowo uzasadniony stosunek podległości politycznej i ekonomicznej, posługuję się nim w tekście.
} 
Gospodarka Polski folwarczno-pańszczyźnianej opierała się w całości na pracy niewolnej (Kula 1993: 41), a taki rodzaj pracy warunkował proces dyskursywnego i symbolicznego podporządkowania chłopów (Burszta 2014: 194-195). Proces ten zachodził w dwóch wymiarach. W pierwszym doszło do politycznego i ekonomicznego podporządkowania pracowników rolnych (przywiązanie do ziemi, pańszczyzna), w drugim wymiarze tę złożoną grupę określono jako „inną” (chłop - niewolnik), odmienną rasowo (ideologia sarmackiego pochodzenia szlachty i "chamskiego" chłopów) i w ten sposób stworzono system dyskursywnego podporządkowania chłopów ${ }^{3}$ (Kuligowski 2016: 73; Blackburn 2010: 12). Mówiąc nieco inaczej, chłopi musieli zostać pozbawieni podmiotowości i człowieczeństwa, bo tylko w ten sposób system pracy niewolnej mógł się utrzymać i reprodukować. Nawet jeżeli pańszczyzna nie wypełnia do końca historycznej definicji niewolnictwa, to chłopi byli postrzegani przez szlachtę jako niewolni; tak funkcjonowali w prawie czy chociażby w literaturze. Przedmiotem moich badań jest zatem przede wszystkim proces ekonomiczny, który doprowadził do powstania pracy niewolnej oraz jednocześnie polityczne i kulturowe osadzenie postrzegania chłopów jako niewolników (polityczne znaczenie rasizmu).

\section{Konteksty pracy niewolnej}

Punktem wyjścia mojego artykułu jest pojęcie pracy niewolnej, przy czym przyjmuję, że określenie „niewolnik” - szczególnie chodzi mi tutaj o jego stosowanie między XVI i XX wiekiem - posiadało wiele różnych politycznych kontekstów użycia. W okresie tym mogło ono być używane na określenie stosunku podległości amerykańskich liberałów względem monarchii angielskiej w czasie rewolucji a merykańskiej i określało poddanego króla (nazwa "niewolnik” była używana jako strategia retoryczna). Określenie to stosował także Piotr Skarga w swoich kazaniach, by napiętnować stosunek panów do chłopów w okresie pańszczyźnianym. Niewolnikami byli też oczywiście Afrykańczycy, łapani i przywożeni do pracy na plantacjach tych samych ludzi, którzy oskarżali monarchię angielską o niewolenie podatkami (Losurdo 2011: 35-37). Zagadnienie niewolnictwa lepiej wyjaśnia zatem spojrzenie na nie od strony stosunków ekonomicznych, niż retoryki (zob. Pobłocki 2016: 63-65). Sytuacja oso-

\footnotetext{
${ }^{3}$ Jednym z elementów takiego „rasowego” dyskursu było także określenie chłopów jako potomków biblijnego Chama. Robin Blackburn wskazuje, że w ten sam sposób uzasadniano biblijne pochodzenie czarnych niewolników.
} 
bista czarnoskórego niewolnika kupionego przez Stefana Batorego czy Andrzeja Fredrę była o niebo lepsza od sytuacji czarnoskórego niewolnika pracującego na plantacji w Ameryce. Bez wątpienia jednak zarówno jednych, jak i drugich łączy to, że są zmuszeni do oddawania swojej pracy za darmo. Stąd też wydaje się, że precyzyjniejsze będzie definiowanie sytuacji chłopów przez pryzmat „pracy niewolnej”, bo opisuje ona obiektywny aspekt rzeczywistości społecznej, jakim jest wymuszanie darmowej pracy na jakiejś grupie lub jednostkach. W ten sposób rozpoznamy, że istnieje głębokie podobieństwo między pańszczyźnianym chłopem na terenie Polski i Afrykańczykiem na plantacji amerykańskiej, choć możemy także wykazać daleko idące różnice między nimi. Chłopami handlowano, ale nie w sposób zinstytucjonalizowany; chłop polski posiadał własność, co prawda zależną, ale jednak. Podobieństwo opiera się na wymuszanym siłą obowiązku oddawania części swojej pracy na rzecz pana, właściciela czy innej nadrzędnej instancji.

W określeniu pracy niewolnej (jak przy każdym rodzaju pracy) możemy wyróżnić jej podział wewnętrzny na pracę właściwą i reprodukcję siły roboczej. Własność zależna, a więc ten kawałek ziemi, jaki chłop otrzymywał „na wynajem”, była przeznaczona na produkcję mającą zapewnić mu byt oraz odnowienie sił. Do tej części pracy włącza się także praca kobiet związana z rodzeniem i wychowaniem dzieci (Federichi 2009: 86-90). To wszystko stanowiło reprodukcję siły roboczej. Pozostały czas w przypadku chłopów przeznaczony był na pracę niewolną i ewentualnie uzyskanie jakichś nadwyżek, które sam chłop mógł spieniężyć, a w przypadku czarnoskórych była to tylko i wyłącznie praca niewolna (Genovese 1989: 48-58).

\section{Chłopi i prawo własności}

Sytuacja prawna chłopa polskiego pokazywała pewną ewolucję prawa własności. Od czasów prowadzonego na ziemiach polskich osadnictwa niemieckiego chłopi mieli co prawda status ludności zależnej (co było cechą charakterystyczną ustrojów feudalnych), jednak posiadali także własność ziemską, za którą uiszczali czynsze. Pomiędzy XII i XIV wiekiem sytuacja chłopów wyglądała względnie korzystnie. Chłopi ze wsi będących z nadania własnością panów dominialnych przenosili się na wsie oparte na prawie niemieckim, a więc na ziemie oczynszowane. Wprowadzenie prawa niemieckiego pozwalało ustalić prawo chłopa do ziemi. 
Ustalił się on na poziomie dziedzicznego posiadania, które przybrało formę własności użytkowej. Stanowiła ona własność podległą wobec własności zwierzchniej pana dominialnego. Był to stosunek podobny do stosunku lennego (Makiłła 2008: 100).

System czynszowy polegał na tym, że rozliczano się za korzystanie z ziemi, przy czym w przypadku kolonizacji obowiązywało zwolnienie z czynszów na czas zagospodarowania (tzw. wolnizna i immunitety); zwolnienie mogło się rozciągać na czas od 2 do 24 lat. Czynsze były płacone w pieniądzu, zbożu lub w sposób mieszany (Makiłła 2008: 100). Sytuacja chłopów zaczynała się radykalnie zmieniać w XIV wieku. Jeszcze w przywilejach budzińskim (1355) i koszyckim (1374) chłopi byli wymieniani jako stan o pewnej osobowości prawnej. Później znikają jako osobny stan i zaczynają się pojawiać najczęściej jako własność szlachty. Statut warecki, który określał warunki tzw. skupu sołectw, stanowił pierwsze wskazanie tego, co zaczyna się dziać w stosunkach własności. Pojawiła się w nim możliwość przejęcia przez panów wsi, do których wprowadzono wójta, który był bezpośrednim przedstawicielem pana (Makiłła 2008: 102).

Dla stwierdzenia faktycznego stanu chłopów ważne były dwa wydarzenia w obszarze prawa. Pierwszym były statuty piotrkowskie z 1496 roku, które wprowadzały przywiązanie chłopów do ziemi ${ }^{4}$, a drugim przywilej toruńsko-bydgoski z 1520 roku. Wprowadzały one obowiązek odpracowywania za darmo na polu właściciela wsi jednego dnia w tygodniu od łana pola posiadanego przez chłopa (poza czynszami, podatkami na rzecz państwa i dziesięciną na rzecz Kościoła). Statut toruński wprowadzał ponadto możliwość ustalania wysokości pańszczyzny w zależności od decyzji pana. W rezultacie chłopi utracili możliwość dysponowania sobą (przywiązanie do ziemi), dysponowania własnym czasem (obowiązek pracy na pańskich polach), stracili także prawo własności ziemi, które zastąpione zostało przez własność zależną od pana. Dodatkowo statuty z 1518 roku wprowadzały zakaz odwoływania się chłopów do sądów państwowych (królewskich), sądownictwo zostało przekazane w ręce pana. Sądowi przewodniczył wójt, a sądzono w oparciu o prawo niemieckie, prawo zwyczajowe i prawo wprowadzone przez pana, który od tego momentu był jedynym prawodawcą i suwerenem chłopów (Makiłła 2008: 102-104). Chłopi nie

\footnotetext{
${ }^{4}$ Rok później wprowadzono podobne prawo na terytorium Rosji, z tym że tam chłopi mieli prawo przenosić się tylko w ciągu tygodnia po 26 listopada, kiedy płody rolne były zebrane i migracja nie zakłócałaby pracy.
} 
mogli także zawierać związków małżeńskich bez zgody pana, a jeżeli wybranka pochodziła $\mathrm{z}$ dóbr innego pana, taka zgoda była niemożliwa.

Sytuacja chłopów nie jest analogiczna do sytuacji Afrykańczyków pracujących na plantacjach, a podstawowa różnica między nimi polega na tym, że właściciele niewolników mieli prawo własności względem konkretnych ludzi. Na terytorium Polski występowała inna zależność. Szlachta miała prawo własności względem ziemi, do której przywiązani byli chłopi. W obu przypadkach mamy jednak do czynienia $\mathrm{z}$ ubezwłasnowolnieniem.

\section{Polityka nadwyżek produkcji}

Gospodarka chłopska jako taka, od czasów średniowiecza, opierała się na podwójnej produkcji - na potrzeby własne (konsumpcja) oraz produkcji towarów przeznaczonych na lokalny rynek (nadwyżka). Sprzedaż na lokalnym rynku była pierwszym zalążkiem nowoczesnego obiegu rynkowego. Nadwyżka towarowa była sprzedawana i za tak uzyskane pieniądze nabywano inne towary, np. rzemieślnicze. W ten sposób powstawała lokalna koniunktura i lokalny obieg towarów. Wraz z odkryciami geograficznymi, oczywiście oprócz złota i szlaków handlowych, pojawiły się możliwości objęcia w posiadanie rozległych ziem, których wielkość pozwalała na skoncentrowanie się wyłącznie na produkcji nadwyżek. Innymi słowy duże terytoria pozwalały na produkcję na własny użytek i wytwarzanie znacznej ilości nadwyżek. W rozwiniętym modelu handlowym sama produkcja nadwyżek dostarczała kapitału wystarczającego na zabezpieczenie własnej konsumpcji. Ten model produkcji na rynek i wytwarzania nadwyżek stał się kluczowy dla powstania i utrwalenia systemu gospodarki folwarczno-pańszczyźnianej.

Robert Brenner podaje trzy główne modele interpretacyjne przejścia między feudalizmem i kapitalizmem. W pierwszym modelu - maltuzjańskim - wskazuje się na to, że dostępność żywności oraz warunki biologiczne determinują rozwój. Drugi model podkreśla znaczenie procesów ekonomicznych, takich jak upowszechnianie się obiegu pieniężnego, pojawienie się obligacji, ubezpieczeń czy też, co niezwykle ważne, kredytu. Trzeci model jest modelem klasowym. Kładzie on nacisk na walki klasowe toczące się pomiędzy XIV i XVI wiekiem, które prowadziły do obalenia feudalnej pracy zależnej i przejścia do modelu handlowego, rynkowego czy też ogólnie kapitalistycznego (Brenner 1995: 10-11). Model ten jest dla nas o tyle 
interesujący, że rozstrzyga kluczową kwestię w próbach rozumienia pańszczyzny w kategoriach feudalnej pracy zależnej bądź niewolnictwa. Walki klasowe w feudalizmie dążyły do obalenia modelu pracy zależnej i przede wszystkim do zmiany systemu własności. Dzięki nim w Europie Zachodniej przestał funkcjonować model rolnika jako rodzaju własności, a zaczął upowszechniać się model rolnika-dzierżawcy lub rolnika-właściciela opłacającego czynsze, podatki itp. W każdym z tych dwóch przypadków mamy nadal do czynienia z rolnikiem produkującym na rynek i na własne potrzeby, na którego, w zależności od okresu i układu politycznego, nakładano dodatkowe obciążenia. Relacja produkcji konsumpcyjnej i nadwyżek na rynek w przypadku oczynszowania nie została zachwiana.

$\mathrm{Na}$ terenie Polski zaszedł jednak zupełnie inny proces. Otóż w okresie kiedy Europa feudalna XIV wieku pogrążona była w kryzysie, który miał doprowadzić do spadku ilości kapitału i w rezultacie do walk klasowych, Polska była relatywnie spokojna i wstąpiła na drogę rozwoju gospodarczego (Topolski 2003: 41). Stało się tak z kilku powodów; dość powiedzieć, że miała wtedy miejsce akcja kolonizacji (rozpoczynająca się dużo wcześniej) polegająca na zasiedlaniu dużych połaci nieużytków przez osadników, którzy byli oczynszowani i zwolnieni z podatków. Posiadali własne instytucje sądownicze i samorządowe, nie byli więc jeszcze w tak tragicznej sytuacji, jak w okresie pełnej pańszczyzny. W reakcji na wyżej przypomniane zachodnie niepokoje, walki klasowe, chaos i kryzys, szlachta Polska, chcąc zabezpieczyć się przed buntem chłopów, przystąpiła do konserwujących feudalizm przemian w swoim stosunku do nich. Istotnymi reformami było przywiązanie chłopów do ziemi i wprowadzenie obowiązku odrabiania pańszczyzny. Czym te dwie rzeczy różniły się od feudalizmu? Pańszczyzna wbrew pozorom nie była konserwatywnym utrzymaniem feudalnych stosunków, ale postfeudalnym politycznym zawłaszczeniem nadwyżek produkowanych przez chłopów. Czas, który chłopi mogli spożytkować na produkcję nadwyżek dla własnych celów i potrzeb rynkowych, był politycznie zawłaszczony przez szlachtę (Kula 1993: 47-49). Dodatkowo wszystkich dóbr, których chłopi nie mogli sami wyprodukować, a które były im potrzebne, dostarczała szlachta za pomocą monopoli: propinacyjnego, młyńskiego oraz w zakresie wyrobów żelaznych, soli, śledzi itp. Nie jest zatem tak, że model rynkowy, który na zachodzie powoli rozwijał się w stronę modelu kapitalistycznego, w Polsce nie zaistniał. Został on zmonopolizowany przez szlachtę. Ograniczyło to i zahamowało wszystkie składniki rozwoju instrumentów rynkowych, takich jak pożyczki 
inwestycyjne, obligacje, tworzenie spółek handlowych; wstrzymało także rozwój technologiczny oraz możliwość popytu na dobra rzemieślnicze i miejskie. Jeżeli zbyt był zagwarantowany monopolem, wystarczyło wyłącznie produkować towary w ten sam sposób; rozwój technologiczny i konkurencja, a więc dwa najistotniejsze dla rynku zachodniego czynniki, zostały znacznie ograniczone.

Tym sposobem szlachta zapewniła sobie kontrolę nad nadwyżkami produkcji, odbierając je zniewolonym chłopom. Mechanizm ten był podobny do przejęcia nadwyżki produkcji w koloniach. Tamtejszy system pracy niewolniczej był na tyle „efektywny”, że dostarczał znacznych nadwyżek kapitału, które mogły być przeznaczane na rozszerzanie produkcji towarowej, ale też na inwestycje i rozwój instrumentów finansowych. W Polsce ten drugi czynnik, ze względu na monopole, został zahamowany; wystąpiło tu zjawisko a kumulacji kapitału (z pracy niewolnej chłopów), nie rozpoczęły się natomiast wszystkie inne procesy kluczowe w rozwoju kapitalizmu. Stało się tak ze względu na ich zahamowanie przez szlacheckie monopole względem miast, rozwoju przemysłu, technologii itd.

Kluczową sprawą dla modelu gospodarki kapitalistycznej jest zatem wspomniana nadwyżka produkcji, a więc to, kto będzie nią zarządzał. Pojawiły się pytania, do kogo ona należy? Kto ją wyprodukował? Jeżeli analizujemy gospodarki oparte na pracy niewolnej, w których mamy do czynienia z zależnością między kosztami produkcji i zyskiem uzyskiwanym z nadwyżki, to opisujemy najczęściej model z amerykańskich kolonii lub chociażby z San Domingo. Były to wielkie farmy nastawione wyłącznie na produkcję nadwyżek, wprowadzanych następnie na światowy rynek obrotu trzciną cukrową, bawełną itd. Ponadto były to przedsiębiorstwa zarządzane przez osobę podległą królowi, ale działającą w dość dużym oddaleniu do niego. Taki zarządca był rozliczany z efektywności produkowania nadwyżki; efektywność uzyskiwano w różny sposób, ale zawsze wiązała się ona z tym, co w naszym modelu produkcji określiłem jako reprodukcję. Im mniej wydamy na wyprodukowanie czegoś, tym więcej zyskamy przy sprzedaży. Reprodukcja w tym modelu odnosiła się do siły roboczej i maszyn. Zwiększenie nadwyżki można było uzyskać przez rozwój technologii uprawy i zbiorów, wzrost efektywności siły roboczej lub obniżenie jej kosztów. Najtańszym, najszybszym rozwiązaniem było to ostatnie i oznaczało po prostu zmuszenie za pomocą różnych środków grupy ludzi do darmowej pracy. Praca niewolnicza jest najtańszym modelem pracy, w każdym innym przypadku robotnikom należałoby płacić za ich pracę, co zwiększałoby koszty reprodukcji, 
a więc zmniejszało nadwyżkę. Ponadto na niewolnika przeznaczano tylko tyle, by utrzymać go przy życiu, zapewniając mu siły niezbędne do pracy. W Polsce proces ten był zdecydowanie bardziej subtelny pod względem podporządkowania nadwyżki, jednak jego konsekwencje są bardzo podobne. Szlachta zapewniła sobie kontrolę nad możliwymi nadwyżkami w produkcji rolnej i następnie sprzedawała je, by zapewnić sobie utrzymanie.

\section{Niewolnictwo i rasizm}

Praktycznie każda definicja niewolnika wskazuje na kilka cech, które muszą zaistnieć w stosunku do osoby, by była uznana za niewolną. W perspektywie historycznej przykładowo prawo rzymskie mówiło o braku podmiotowości prawnej jednostki, przez co mogła ona być przedmiotem handlu. Osoba taka była więc czyjąś własnością tak, jak jest nią rzecz. Swoją własnością można dowolnie dysponować, można ją bezkarnie okaleczyć czy zabić, bo nie regulują jej statusu inne prawa niż prawo własności. Status chłopa tylko pozornie zdaje się wymykać tym klasyfikacjom. Handel chłopami, choć zdarzał się, to nie był zinstytucjonalizowany. Handlowano raczej ziemią, z którą na stałe związani byli chłopi. Natomiast już status prawny chłopów jako podmiotu jest wątpliwy. Otóż stan „chłopski” znika z prawodawstwa polskiego w XIV wieku. Formalnie zabójst wo chłopa nie było ani zakazane, ani dozwolone. W przypadku gdyby pan chłopa zabił, stanąłby przed sądem, którego jest ustawodawcą i nadzorcą, który pozostaje w jego dyspozycji. Z drugiej strony, chłopi posiadali jednak w stopniu minimalnym osobowość prawną, gdyż płacili podatki na rzecz państwa i Kościoła oraz byli powoływani do wojska (Makiłła 2008: 103). Czy rzeczywiście jednak można kategorycznie stwierdzić, że byli niewolnikami? Na każdy taki argument można przywołać kontrargument, odwołując się zarówno do przykładów historycznych, jak i samego prawa. Możemy zatem przyjąć, że nie byli niewolnikami; kim zatem byli? Z pewnością nie ludźmi wolnymi ze względu na wszystkie cechy, jakie wymieniłem powyżej, ich sytuacja była ponadto diametralnie różna od sytuacji chłopów w Europie Zachodniej. Jeżeli będziemy trzymać się ściśle określania niewolnictwa w oparciu o jego krwawe i brutalne formy, jakie znamy z północnoamerykańskich plantacji, to z tej perspektywy nie możemy uznać chłopów za niewolników. W takim wypadku jednak jedną z form niewolnictwa przyjmujemy za jego wzór i podstawę definicyjną. Wtedy za niewolników nie będziemy mogli 
także uznać czarnoskórych łapanych do pracy na europejskich dworach, których sytuacja ekonomiczna była lepsza niż ich pobratymców pracujących na plantacjach (Tazbir 1989: 2-4). Kluczem może być tutaj powstanie w społeczeństwie swoistej „linii demarkacyjnej”, która wyznacza to, kto może być uznany za człowieka, a kim można dysponować jak żywym inwentarzem.

Jak pokazał to Eric E. Williams, niewolnictwo było pierwotne wobec rasizmu w czasach rodzącego się kapitalizmu. Niewolnictwo w pierwszej kolejności opiera się na ekonomii, rasizm jest dopiero jego pochodną (Williams 1994: 31). W nowożytnej formie rasizm narodził się wraz z niewolnictwem i bezpośrednio wiąże się on z uzasadnieniem utrzymania całej grupy ludności w stanie podległości. Howard Zinn wskazuje, że jeszcze w XVII wieku dość częste były sytuacje, kiedy wobec wspólnych problemów biali i czarni wykonywali pracę na rzecz ich pokonania razem, podobnie jak wtedy, kiedy konfrontowali się ze wspólnym wrogiem. Dopiero pod koniec wieku wprowadzono prawo zabraniające takiego współdziałania, praktyka ta musiała zatem być dość istotna. Przykładowo w 1691 roku w Wirginii prawo stanowiło, że wygnano każdego „wolnego białego mężczyznę lub wolną białą kobietę, którzy zawierali związki małżeńskie z czarnymi, mulatami lub Indianami płci obojga, zarówno wolnymi, jak i niewolnymi" (Zinn 2016: 63). Dla H. Zinna samo stwierdzenie, że rasizm jest konstruktem społecznym nie wystarcza, bo może wskazywać na jakąś naturalną skłonność społeczeństwa do tworzenia rasizmu. Łączyłby się on w takim przypadku z antropologiczną opozycją swój-obcy (zob. Burszta 2013: 138-140) i wtedy rzeczywiście mógłby uchodzić za naturalny. Amerykański badacz podaje jednak, że do tego, że rasizm jest społecznym konstruktem, należy dodać także w kontekście amerykańskiego rasizmu historię podporządkowania, pieniądze zachęcające do wyzysku i zniewolenia, desperacką wolę przetrwania kolonistów wymagającą pracy przymusowej (Zinn 2016: 62).

Trzon niewolników stanowili ludzie o odmiennym pochodzeniu etnicznym, niebędący częścią danej grupy kulturowej. Na niewolników łapano przedstawicieli innych plemion w Afryce, czy, w średniowiecznej Europie, Słowian. Trwanie w tym niewolniczym stanie musiało być uzależnione od stosunku władzy. Stąd pojawienie się zjawiska rasizmu. Różnice etniczne między grupami kulturowymi nie zakładają koniecznie stosunków podległości. Po prostu powszechnie nie łapie się na niewolników członków swojego plemienia, członkowie własnego „plemienia” tylko indywi- 
dualnie mogli podpadać pod „niewolnictwo" . Ekonomiczny i fizyczny wyzysk jest tym bardziej możliwy, im większa jest różnica w kulturowych tożsamościach. Chodzi o to, że rasizm nie jest bezpośrednio zawarty w starej antropologicznej opozycji my-oni. Rasizm jest dopiero nałożeniem na tę zasadę optyki ekonomicznej podrzędności. Podrzędność umożliwia utrzymanie stosunku niewolniczego wyzysku, pozwala jednocześnie na pacyfikowanie możliwego sprzeciwu. Polityczny rasizm, a więc oparcie prawa na rasizmie, powoduje, że obojętne są w nim indywidualne przekonania. Innymi słowy gdyby jakiś właściciel niewolników został tknięty wyrzutami sumienia, nie walczyłby tylko ze swoim indywidualnym rasizmem, ale występowałby przeciwko prawu w ogóle.

\section{Chłop - niewolnik?}

Określnie chłopa w badaniach oraz dyskursie potocznym jako niewolnika napotkało już w XX wieku pewien problem. Tradycja marksistowskich badań historycznych (mniej lub bardziej powiązanych z sowiecką wykładnią historii), która niejako z założenia winna badać kwestię wyzysku, była skażona pewnym dogmatem i, jak pokazał to Richard Hellie, odcisnął on duże piętno na opisywaniu sytuacji chłopstwa. Historia powstania wyzysku jest złożona, dlatego pozwolę sobie na zarysowanie jej skróconej wersji. Dogmat ten miał służyć uzasadnieniu wpisania chłopów w strukturę gospodarki radzieckiej po NEP-ie, w której byli oni poddani przymusowej kolektywizacji. Struktura kolektywizacji do złudzenia przypominała pracę na polach właścicieli ziemskich z okresu pańszczyzny. Wprowadzono więc zmianę w interpretacji historii (polityce pamięci) i stwierdzono, że niewolnictwo skończyło się wraz ze średniowieczem; okres późniejszy (a więc okres pańszczyzny w Rosji) był już okresem innych stosunków. Zmiana ta odcisnęła piętno na całej historiografii dotyczącej pańszczyźny. Porównywano wręcz pańszczyznę do współczesnych podatków.

System na radzieckiej wsi, który ostatecznie załamał się po 1917 roku, był kontynuacją systemu, jaki panował od końca średniowiecza, a którego nie chciano nazywać „niewolniczym”. Nieustanna groźba, że chłopi rosyjscy zbuntują się przeciwko sowieckiej władzy, blokując dostawy żywności i windując ceny, spowodowała, że

\footnotetext{
${ }^{5} \mathrm{~W}$ średniowieczu w Polsce istniała forma niewolnictwa np. za długi, po odpracowaniu której stawało się wolnym człowiekiem.
} 
Stalin radykalizował swój stosunek do wsi (Carr 1979: 50-60). Wprowadzona przez niego przymusowa kolektywizacja oraz konstytucyjna zmiana stosunku do ziemi (chociażby w porównaniu ze słynnym dekretem z 1918 roku) do złudzenia przypominała pańszczyznę, choć oficjalna ideologia nazywała ją „socjalistyczną akumulacją”. Stalinowska wizja historii zakładała więc, że „chłop” (kholop ${ }^{6}$ ) wbrew temu, co znaczy ten wyraz, miał być interpretowany w historiografii nie jako "niewolnik” (Hellie 1976: 1-3), ale ewentualnie jako „poddany”. Celina Bobińska także wskazywała na podobny problem w przypadku buntów chłopskich, które historiografia radziecka zawsze przedstawiała jako niezorganizowane, bezmyślne wybuchy nagiej przemocy, co miało służyć wyparciu pamięci o innych modelach chłopskiej polityczności (Bobińska 1985: 40).

Dogmat ten został opisany przez R. Helliego w tekście, w którym analizuje on historiografię radziecką. Tekst ten wywołał polemikę Herberta Leventera, który zauważył, że wyrazu „kholop” nie powinno się przekładać jako „niewolnik”, ale jako „poddany”. W komentarzu do znaczenia wyrazu „kholop” H. Leventer mówi, że w powszechnej definicji niewolnictwa podkreśla się, że jeżeli nie ma różnic rasowych czy biologicznych, to wtedy buduje się ideologię odmienności opartą na tym, że niewolnik jest głupszy, leniwy, nadpobudliwy seksualnie, nie ma duszy itd. (Leventer 1977: 66). H. Leventer podkreśla, że nie znalazł w rosyjskiej historiografii dowodów na to, że przedstawiano w ten sposób „chłopa” ani też, że odróżniano go w jakiś szczególny sposób od reszty społeczeństwa (Leventer 1977: 66). W Polsce jednak taki stosunek się pojawił i był zawarty w ideologii sarmackiej, tłumaczącej szlachecką wyższość pochodzeniem od rzymskiego plemienia. H. Leventer wskazuje, że „kholop” miał znaczenie niewolnika, ale niekoniecznie niewolnika o niższym statusie społecznym; mogła to być osoba oddająca się w niewolę za długi. „Kholopem” mógł też zostać szlachcic, który chciał uniknąć służby wojskowej i nie umniejszałoby to jego pozycji społecznej. Autor wskazuje, że określenia dystynktywne narzucano raczej niższym klasom, rolnikom, „smerdom”, a więc tym, którzy śmierdzą. Określenia dystynktywne wobec „kholopa” zdaniem Leventera pojawiły się dopiero w okresie oświecenia, kiedy chłopstwo (oryginalnie rozumiane niewolnictwo, a więc jako inny stan ludności wiejskiej obok rolników, bezrolnych itd.) już właściwie nie istniało (Leventer 1977: 66).

\footnotetext{
${ }^{6}$ "Chołop" jest rosyjskim określeniem niewolnika, zapisanym w języku polskim, w języku angielskim zapisuje się ten wyraz jako „kholop”.
} 
Czy można zatem powiedzieć, że na terytorium Polski zdarzył się proces, w którym doszło do połączenia pod względem prawnym i ekonomicznym zróżnicowanej (majątkowo, własnościowo, politycznie i społecznie) grupy trudniącej się uprawą roli w jedną klasę i wykorzystano do jej podporządkowania określenie „kholop”? Wykorzystano by więc w okresie wprowadzenia pańszczyzny określenie „niewolnika", które niekoniecznie oznaczało kogoś pracującego na roli, by określić tak grupę osób i w ten sposób po pierwsze, określić wyraźne granice tej grupy, a po drugie, stworzyć ideologiczne uzasadnienie tej różnicy. Trudno jednak znaleźć bezpośrednie dowody na ideologiczną interpelację „chłop-niewolnik”. Słownik polszczyzny XVI wieku z 1966 roku wymienia znaczenie wyrazu "chłop-niewolnik” jako jedno $\mathrm{z}$ wielu, poza ludnością rolniczą, a w słowniku Aleksandra Brücknera znajdujemy informację, że wyraz ten pochodzi od wyrazu „niewolnik”. O tym, czy faktycznie mieliśmy tutaj do czynienia z praktyką ideologicznego osadzenia ludności wiejskiej w roli „niewolników”, czy z innym procesem, możemy wnioskować tylko na podstawie poszlak i dowodów pośrednich, a więc tego, że ludność wiejska została zbita w jedną warstwę „chłopów” i warstwa ta zniknęła jako osobny stan posiadający osobowość prawną? Jeden z najstarszych zabytków języka polskiego dotyczący rolników, Nazwy ciężarów ludności wieśniaczej, nie wymienia chłopów ani razu, pisze o ludności wieśniaczej albo o „ich wieśniakach” (Nazwy ciężarów...: 28-31).

Jednak możemy jeszcze wskazać na pewną decydującą o statusie chłopów rzecz, jest nią pryzmat, przez jaki uzasadniano niewolnictwo w krajach handlu atlantyckiego: rasizm. Mówiąc ogólnie, jest nią wskazanie na "nieludzkie” bądź „podrzędne” pochodzenie grupy ludzi ze względu na pewne cechy. Badacze są w zasadzie zgodni co do tego, że niewolnictwo wiązało się przede wszystkim z postrzeganiem grupy niewolonej jako innej rasowo, etnicznie lub, jeżeli niewolnicy pochodzili z tej samej grupy etnicznej, jako gorszej, leniwej, rozpasanej seksualnie itd. (Leventer 1977: 66). Robin Blackburn wskazuje, że w zasadzie niewolnictwo w krajach słowiańskich (terytorium Polski, Rosji) było w tym względzie wyjątkiem, to znaczy niewolnicy pochodzili z tej samej grupy etnicznej (Blackburn 2010: 55). W Rosji jednak niewolnik niekoniecznie był podrzędniejszego statusu, ponadto niewolnicy to przede wszystkim służba domowa, jacyś drobni robotnicy, czasem, choć rzadko, także bajlifowie, a na terenie Polski parobcy. Sytuacja diametralnie zmieniła się

\footnotetext{
${ }^{7}$ Nie spotkałem się z tym, żeby w innym niż polski języku określenie „niewolnik” przetrwało jako określenie ludności rolniczej, wiejskiej. Nawet w rosyjskim wyraz „chołop” oznacza raczej niewolnika (też chłopskiego) niż ogólnie ludność wiejską.
} 
wraz z erą nowożytną. Wydaje się, że szlachta polska przejęła określenie „chołop” oznaczające niewolnika (ale niekoniecznie rolnika) i zaczęła w ten sposób określać grupę zajmującą się uprawą roli.

Pomiędzy XIII i XV wiekiem nastąpiło ujednolicenie się stanu chłopskiego. Wcześniejsze kategorie ludności wiejskiej, o różnym statusie, majątku i pozycji prawnej (jak: goście, zakupy, przypisańcy, dziesiętni, narocznicy, niewolnicy itd.), w XIV wieku zaczęły zanikać na rzecz jednego stanu: chłopskiego. Stan ten był ujęty w prawie jako posiadający ograniczone prawo wychodu ze wsi, prawo nadziału ziemi czy ustalone czynsze. Jako stan chłopi posiadali więc osobowość prawną, która wraz z wprowadzeniem pańszczyzny zaczęła znikać; od XV wieku chłopi przestali być osobnym stanem i stracili tę osobowość (Heck 1970: 198-197). Co ciekawe w dokumentach przywiązujących chłopów do ziemi, a więc w statucie Jana Olbrachta (tzw. statucie piotrkowskim z 1496 roku) mowa jest o kmieciach (kmiecie byli chłopami posiadającymi ziemię), jako o ludności wiejskiej lub o ludności plebejskiej, ale już statut toruński z 1520 roku mówi tak:

Kmiecie winni pracować mniej lub więcej jeden dzień w tygodniu. A także pragnąć zaradzić pożytkowi naszych poddanych za radą i zgodą wszystkich Panów Rady naszych obojga stanów oraz Posłów Ziemskich Królestwa naszego stanowimy i postanawiamy, aby było zawsze przestrzegane: aby, wszyscy i pojedynczy chłopi [podkreślenie M.R.], czyli kmiecie wszystkich i poszczególnych wsi [...] nam i swoim panom $\mathrm{z}$ każdego łanu jeden dzień tygodniowo odpracowywali [...] (Statut toruński...: 16).

\section{Sarmatyzm i chłopi}

Ekonomiczna eksploatacja chłopów przez szlachtę napotykała bardzo poważny problem - moralne uzasadnienie. Postępującemu od XVI wieku zaostrzeniu pańszczyzny musiało towarzyszyć uczucie swoistego moralnego niepokoju, które było wygaszane na dwa sposoby, z tym że pierwszy z czasem zaczął przygasać na rzecz drugiego. Pierwszy zawierał się w paternalistycznym stosunku do chłopów, którego korzeni należy szukać w średniowiecznych stosunkach feudalnych. U jego podstaw tkwiło założenie, że pan przejawia ojcowski stosunek względem chłopa, który jest niewykształcony i nieuświadomiony. Pan dba o niego, daje mu ziemię, a więc źródło utrzymania (Matuszewski 1991: 38). Drugi sposób polegał na wytworzeniu ideologii odmiennej etnicznej (czy protorasowej) genealogii chłopów 
i szlachty. Taką ideologią było wywodzenie pochodzenia szlachty od mitycznego rzymskiego (choć to bywa dyskusyjne) plemienia Sarmatów.

Po raz pierwszy sarmackie pochodzenie szlachty zostało określone w pracy pt. Traktato dwu Sarmacjach azjatyckieji europejskieji ich zawartości Macieja Miechowity, która ukazała się w 1518 roku (Bogucka 2016: 39). Przekonanie to pojawia się w także pracach Wincentego Kadłubka, Jana Długosza czy Alessandro Guagniniego (Sarmatiae Europeae Descriptio). Ideologia ta ma wiele różnych obliczy oraz funkcji. Przykładowo w XVI wieku po unii lubelskiej i powstaniu Rzeczy pospolitej Obojga Narodów, czyli de facto w momencie tworzenia się nowożytnego państwa, posłużyła jako jej spoiwo ideowe. W tym samym czasie jednak kształtował się system gospodarki folwarczno-pańszczyźnianej i w relacji do niego sarmatyzm miał przede wszystkim wprowadzać ostrą dystynkcję protorasową między szlachtą i chłopami. Zaostrzała się ona wraz z coraz intensywniejszym wyzyskiem ekonomicznym. W teorii etnogenetycznej mit sarmacki spełniał więc dwie funkcje: spajał tożsamość narodu szlacheckiego oraz utrwalał jego hegemonię przez wskazanie na pierwszeństwo biblijnego Sema - protoplasty szlachty, wobec Chama - przodka niższych stanów oraz Jafeta reprezentującego Żydów (Nowicka-Jeżowa 2009: 211-219).

W genealogii handlu niewolnikami istotne miejsce zajmuje dystynkcja na pochodzenie od biblijnego syna Noego - Chama. Zgodnie z funkcjonującą od czasów średniowiecza w Europie wykładnią, Cham miał dać początek ludom w północnej Afryce, na dzisiejszym terytorium Egiptu, Libii, Etiopii, a nawet na ziemiach arabskich i w Palestynie. Ponadto dowodzono, że był on ciemnoskóry i niektóre tradycje interpretacji rzeczywiście w ten sposób uzasadniały niewolnictwo (Blackburn 2010: 67). W słynnej książce Nowe Ateny Joachima Benedykta Chmielowskiego genealogia „ras” ludzkich także dzieli się w stosunku do potomków Noego. Wyróżnia on: Jafetydów - jasnowłosych i jasnoskórych mieszkańców Europy, Semitów - ludność Azji o ciemnych włosach i oczach i Chamitów - czarnoskórych mieszkańców Afryki (Kowalczyk 2014: 230). Choć praca ta ukazała się w XVIII wieku, to dość dobrze ukazuje ona splot powiązań między chłopami a „czarnymi potomkami Chama”, który musiał oddziaływać na wyobraźnię między okresem, kiedy się pojawił (XVI w.) i momentem wydania pracy Chmielowskiego.

W kontekście polskim, jak podaje Józef Matuszewski, pojęcie „chama” pojawiło się dopiero pod koniec wieku XVI (Matuszewski 1991: 75). Występują wtedy także inne zjawiska, które pozwalają ustalić pewną wspólną ich podstawę. W tym czasie 
upowszechnia się określenie ludności rolniczej wszystkich stanów mianem „chłopów", następuje zaostrzenie pańszczyzny, utrwala i upowszechnia się ideologia sarmatyzmu, której szczytem będzie XVII wiek. Sarmatyzm w formie dystynktywnej pojawia się więc jednocześnie ze wzmożeniem zjawisk związanych z zaostrzeniem niewoli chłopów. Wywodzenie genealogii (czarnoskórych) niewolników od biblijnego Chama było nieco wcześniejsze, bo pojawiło się w początkach XV wieku. Nie bez przyczyny więc zniewolenie chłopów zaczynało być w podobny sposób uzasadniane w kontekście pańszczyzny. Wraz z zaostrzaniem się pańszczyzny ludność rolnicza zaczynała być określana jako chamy i chłopi. O ile jeszcze na początku XVI wieku synowie bogatych chłopów uczęszczali na Uniwersytet Krakowski, ponadto zdarzały się mieszane małżeństwa, to wraz z postępującą praktyką dystynkcji szlacheckiej zostało to praktycznie całkowicie wyeliminowane (Topolski 2015: 42).

$\mathrm{W}$ przypadku niewolnictwa atlantyckiego fizyczna różnica w kolorze skóry z czasem została przekuta w uzasadnienie podrzędności byłych mieszkańców Afryki. W przypadku chłopów o takiej fizycznej odrębności nie było mowy ${ }^{8}$. Szlachta w ideologii sarmatyzmu wytworzyła więc szereg praktyk dystynktywnych, których posiadanie lub nieposiadanie miało określać przynależność do stanu szlacheckiego lub chłopskiego. Do cech tych można zaliczyć: gestykulację, zbiór obyczajów i norm, strój czy specyficzną mowę (łączącą zwroty polskie i łacińskie). Walerian Nekanda Trepka tropił chłopów podszywających się pod szlachtę i wyniki opublikował jako słynne Liberum Chamorum. Jest to praca, w której bada on, kto ma prawo określać się jako szlachcic. Przykładowo chłopa podszywającego się pod szlachcica demaskowało to, że: „mowę chłopską miał, szepluniawą i prostak w obyczajach” (zob. Tazbir 2013: 24). Biorąc pod uwagę to, że od końca XVI wieku właściwie nie zdarzało się, żeby chłop awansował społecznie, można domyślać się, że praca ta stanowiła raczej wyraz swoistej „biopolityki bycia szlachcicem”. Z jednej strony, określała genealogie szlacheckiego pochodzenia, z drugiej, wskazywała na szereg praktyk dystynktywnych, których wykonywanie miało stanowić potwierdzenie szlacheckiego stanu. Przykładowo fałszywego szlachcica demaskowała nieznajomość etykiety: „słał jej wieńce na półmisku, drugim przykrywszy. $Z$ tego i innych postępków poznano, że chłop, i odmówiono mu" (zob. Tazbir 2013: 24).

\footnotetext{
${ }^{8}$ Ponadto pomiędzy szlachtą i chłopami nie było różnicy wyznaniowej, wyjątek stanowiły tutaj kresy, gdzie ludność rolniczą, ale niemającą praw kozackich, określano mianem „czerni”.
} 
Wprowadzenie symbolicznych praktyk dystynktywnych przez szlachtę, poza walorem konsolidacji narodu szlacheckiego, miało przede wszystkim wymiar radykalnego oddzielenia się od chłopów. Tym samym praktyki te stanowiły odpowiednik fizycznej różnicy, na której opierał się rasim, jaki towarzyszył niewolnictwu. Zarówno $\mathrm{w}$ jednym, jak i w drugim przypadku, takie różnicowanie ma wymiar moralny, pozwala uciszyć jakiekolwiek wątpliwości co do systemu ekonomicznego wyzysku. W sytuacji, kiedy mamy do czynienia z „innym” (chłop, „czarny”), dużo łatwiej jest przejść nad jego kondycją do porządku dziennego.

\section{Wnioski końcowe}

Eric R. Wolf wskazuje, że jednym z głównych czynników dyscyplinujących ludność rolniczą było postrzeganie i projektowanie ich jako gorszych, leniwych, nadpobudliwych seksualnie, irracjonalnych (zob. Wolf: 1966; Willis: 1981). Podobny stosunek występuje w przypadku relacji względem kobiet (wykorzystuje się te same schematy). Kobiety opisuje się przez pryzmat irracjonalizmu czy nadmiernego popędu seksualnego (Theweleit: 2015). Bez dużej przesady możemy więc powiedzieć, że wraz z ekonomiczną podległością (by nie powiedzieć wyzyskiem) idą kulturowe formy dystansu i dyscypliny. Na podobne zjawisko wskazuje Pierre Bourdieu, w którego teorii pól symbolicznych i symbolicznych kapitałów odnaleźć można czynniki dystynktywne. Ekonomiczna wyższość jest w nich przepracowywana na wyższość „kulturalną”. Klasowość jest uzasadniana przez wyższość kulturalną, wyższość gustu i dostępu na przykład do sztuki wysokiej (Bourdieu 2005: 43). Możemy więc pokusić się o wprowadzenie zależności, w której każda ekonomiczna nierównowaga jest przepracowywana i wpisywana w strukturę kulturową. Mówiąc inaczej, jest konstruowana w taki sposób, że może i mamy tutaj do czynienia z wyższością, ale jest to wyższość niejako zasłużona przez wypełnienie kulturowych warunków dystynktywnych. W teoriach politycznych początku XX wieku dowodzono, że tylko mężczyzna może rządzić, gdyż tylko on jest odpowiednio racjonalny i kierujący się logiką ${ }^{9}$ Zarówno w przypadku kobiet, ludności rolniczej, jak i klas niższych za każdym razem możemy bardzo łatwo rozpoznać kulturowe warunki ekonomicznej zależności.

\footnotetext{
${ }^{9}$ Co ciekawe na tej samej zasadzie dowodzono, że „orientalny” inny także nie potrafi sobą rządzić, bo kieruje się instynktami i popędami zamiast logiką (zob. Said 2005: 86-88).
} 
Chłopi byli przedstawiani wraz z całym tym zestawem standardowych środków kulturowej dyscypliny. W przypadku polskiego chłopa mieliśmy jednak do czynienia z czymś jeszcze. W teoriach niewolnictwa (nowożytnego) wskazuje się, że niewolnicy musieli pochodzić z odmiennej etnicznie grupy (bądź wielu grup). $\mathrm{Na}$ terytorium Polski było to sytuacja rzadka ze względu na koszty i wiele innych czynników. Dlatego poddaństwu musiało towarzyszyć wytworzenie radykalnej bariery między chłopami i szlachtą. Nie mógł wystarczyć do tego schemat postrzegania ich jako leniwych czy irracjonalnych. Tym radykalnym oddzieleniem się szlachty od chłopów była nowożytna koncepcja narodu - ideologia sarmatyzmu. W ten sposób wytworzyła się swoiście „rasowa” zależność, w której chłopi byli postrzegani jako nieomalże „niższa rasa” (w czasach jej tworzenia nie było jeszcze podziałów rasowych, które są nowoczesnym wynalazkiem). Status ten odróżnia polskiego chłopa (niewolnika) od poddanego rolnika Europy Zachodniej dlatego, że pomiędzy poddanym a panującym wytwarza się zależność polityczna oparta na ekonomii, która jest uzasadniana za pomocą schematów postrzegania rolników jako np. leniwych. W przypadku polskich chłopów ta zależność przechodzi we własność. Chłop staje się własnością szlachcica razem z uprawianą przez siebie ziemią. Do utrzymania takiego statusu nie wystarczą same dyscyplinujące narzędzia, musi wiązać się z tym odmienna ideologia. Ta ideologia opiera się na schemacie, który później, w czasach nowoczesnych, nazwany zostanie teorią rasowego pochodzenia.

Proces narzucania niewolnictwa i rasizmu rozumianego $w$ formie kulturowego uzasadnienia nierówności jest zatem stopniowalny. Możemy wskazać ich wzajemne połączenie przez rozpoznanie procesu ekonomicznej nierówności czy ekonomicznego wyzysku, który jest opracowywany przez kulturowe uzasadnienie tej nierówności. Proces ten przechodzi kilka stopni i im bardziej jest on intensywny, tym radykalniejsze staje się jego uzasadnienie.

$\mathrm{W}$ artykule tym starałem się pokazać kontekst narzucenia ludności rolniczej na terytorium Polski pracy niewolnej. Z taką formą nierówności musiało wiązać się jej kulturowe uzasadnienie w postaci dyskursu o odmiennym pochodzeniu, które miało uzasadniać wyzysk (pochodzenie sarmackie, koncepcja nowożytnego narodu). Dzięki takiemu ujęciu problemu możemy w inny sposób podejść do definiowania tego, co rozumiemy pod pojęciem niewolnictwa - mówimy raczej o wypełnieniu jego zdefiniowanych warunków, takich jak brak podmiotowości prawnej, relacje własności. Moja propozycja koncentruje się na obecności pracy niewolnej, stopniu jej intensywności oraz 
kulturowym uzasadnieniu trwania. Uzasadnienie to balansuje na granicy pomiędzy uznaniem chłopa-niewolnika za „człowieka” i „nieczłowieka” zarazem.

\section{Bibliografia}

Anderson, P. (2013). Passages from Antiquity to Feudalism. New York-London: Verso.

Arendt, H. (1991). O rewolucji (przeł. M. Godyń). Kraków: Wydawnictwo X, Dom Wydawniczy Totus.

Baczko, B. (2010). Rewolucja. Władza, nadzieje, rozterki (przeł. W. Dłuski). Gdańsk: słowo/obraz terytoria.

Blackbourn, R. (1997). The Old World Background to European Slavery. William and Marry Quarterly. Third Series, 54 (1), 65-102.

Blackburn, R.(2010). The Making of New World Slavery. From the Baroque to the Modern. 1492-1800, London-New York: Verso.

Boas, G. (1969). Vox populi. Essay in the History of an Idea. Baltimore: John Hopkins Press.

Bobińska, C. (1985). O przywódcach chłopskich w Polsce w XVIII i XIX wieku, W: S. Michalkiewicz (red.), Wybitni i przeciętni przywódcy a lud i społeczeństwo w dziejach (ss. 39-54). Katowice: Wydawnictwo Uniwersytetu Śląskiego.

Bogucka, M. (2016). Kultura sarmatyzmu w Polsce XVI-XVIII wieku. Warszawa: Wydawnictwo Neriton.

Bourdieu, P. (2005). Dystynkcja. Społeczna krytyka władz sądzenia (przeł. P. Biłos). Warszawa: Wydawnictwo Naukowe Scholar.

Brenner, R. (1995). Agrarian Class Structure and Economic Developement in Pre-Industrial Europe. W: T.H. Aston, C.H.E. Philpin (red.), The Brenner Debate. Agrarian Class Structure and Economic Developement in Pre-Industrial Europe (ss. 10-64). Cambridge: Cambridge University Press.

Buck-Morss, S. (2014). Hegel, Haiti i historia uniwersalna (przeł. K. Bojarska). Warszawa: Wydawnictwo Krytyki Politycznej.

Burszta, W.J. (2009). Od mowy magicznej do szumów popkultury. Warszawa: Academia.

Burszta, W.J. (2013). Kotwice pewności. Wojny kulturowe z popnacjonalizmem $w$ tle. Warszawa: Iskry.

Burszta, W.J. (2014). Preteksty. Gdańsk: Wydawnictwo Naukowe Katedra.

Carr, E.H. (1979). The Russian Revolution. From Lenin to Stalin. New York: The Free Press. 
Davis D. B. (2003). Chalanging The Boundries of Slavery, Cambridge-London: Harvard University Press.

Federichi, S. (2009). Caliban and the Witch. New York: Autonomedia.

Feinberg, J.G. (2016). Kto się boi wielkiego, złego folku? (przeł. M. Rauszer), Studia Etnologiczne i Antropologiczne, 16, 15-33.

Foucault, M. (2010). Bezpieczeństwo, terytorium populacja (przeł. M. Herer). Warszawa: Wydawnictwo Naukowe PWN.

Foucault, M. (2014). Rządzenie żywymi (przeł. M. Herer). Warszawa: Wydawnictwo Naukowe PWN.

Genovese, E. (1989). The Political Economy of Slavery: Studies in Economy and Society of Slave South, Middletown: Wesleyan University Press.

Heck, R. (1970). Gospodarka czynszowa (od połowy XIII w. do schyłku XV w.). W: S. Inglot (red.), Historia chłopów polskich, tom I, (ss. 154-245). Warszawa: Ludowa Spółdzielnia Wydawnicza.

Hellie, R. (1976). Recent Soviet Historiography on Medieval and Early Modern Russian Slavery. The Russian Review, 35 (1), 1-32.

Jackson, M. (2005). Existential Anthropology. Events, Exigencies and Effects. New York-Oxford: Berghahn Books.

James, C.J. (1989).The Black Jacobins. Touissaint L'Ouverture and the San Domingo Revolution. New York: Vintage Books.

Kolchin, P. (1987). Unfree Labor. American Slavery and Russian Serfdom. Cambridge-London: The Belknap Press.

Kowalczyk, E.M. (2007). „O różności powierzchniowej mieszkańców ziemi”, czyli rasyludzkie w ujęciu geografów polskich XVIII w. W: F. Wolański (red.), Staropolskiogląd świata- problem inności. Toruń: Wydawnictwo Adam Marszałek.

Kula, W. (1993). Rozwój gospodarczy polski. XVI-XVII wiek. Warszawa: Wydawnictwo Naukowe PWN.

Kuligowski, W. (2016). Chamska historia Polski. Tezy i antytezy, Czas Kultury, 3, 70-80.

Leventer, H. (1977). Comments on Richard Hellie's "Recent Soviet Historiography on Medieval and Early Modern Russian Slavery", The Russian Review, 36 (1), 64-67.

Losurdo, D. (2011). Liberalism. A Counter-History (przeł. G. Elliott). New York-London: Verso. Makiłła, D. (2008). Historia prawa w Polsce. Warszawa: Wydawnictwo Naukowe PWN. Mączak, A. (1986). Rządzący i rządzeni. Warszawa: Państwowy Instytut Wydawniczy. 
Nazwy ciężarów ludności wieśniaczej. Najdawniejsze zabytki języka polskiego (1975). Taszycki, W. (oprac.). Wrocław-Warszawa-Kraków-Gdańsk: Zakład Narodowy imienia Ossolińskich.

Nowicka-Jeżowa, A. (2009). Barok polski między Europą i Sarmacją. Część pierwsza: Profile i zarys całości. Warszawa: Wydawnictwo Neriton.

Pobłocki, K. (2016). Niewolnictwo po polsku, Czas Kultury, 3, 60-70.

Said, E. W. (2005). Orientalizm (przeł. M. Wyrwas-Wiśniewska). Poznań: Wydawnictwo Zysk i S-ka.

Snyder, T. (2006). Rekonstrukcja narodów. Polska, Ukraina, Litwa, Białoruś 1569-1999 (przeł. M. Pietrzak-Merte). Sejny: Fundacja Pogranicze.

Statut toruński. Wybór tekstów źródłowych z historii Polski XVI-XVII w. (1976). Zestawili D. Gradowska, I. Kaniewska, K. Przyboś. Kraków: Uniwersytet Jagielloński.

Tazbir, J. (1989). Przybysze z innych kontynentów, Problemy, 513 (4), 2-4.

Tazbir, J. (2013). Kultura szlachecka w Polsce. Rozkwit - upadek - relikty. Poznań: Wydawnictwo Nauka i Innowacje.

Theweleit, K. (2015). Męskie fantazje (przeł. M. Falkowski, M. Herer). Warszawa: Wydawnictwo Naukowe PWN.

Tilly, Ch. (1997). Rewolucje Europejskie 1492-1992 (przeł. E. Żelazna). Warszawa: Wydawnictwo Krąg. Oficyna Wydawnicza Volumen.

Topolski, J. (2015). Rzeczpospolita obojga narodów 1501-1795. Poznań: Wydawnictwo Poznańskie.

Topolski, J. (2003). Narodziny kapitalizmu w Europie XIV-XVII wieku. Poznań: Wydawnictwo Poznańskie.

Williams, E.E. (1994). Capitalism and Slavery. Chapel Hill-London: The University of North Carolina Press.

Willis, P. (1981). Learning to Labor. How Working Class Kids Get Working Class Jobs. New York: Columbia University Press.

Wolf, E.R. (1966). Peasants. New Jersey: Prentice Hall INC.

Zinn, H. (2016). Ludowa historia Stanów Zjednoczonych (przeł. A. Wojtasik). Warszawa: Wydawnictwo Krytyki Politycznej. 
